\title{
Menneisyyden internet tulevaisuuden historiantutkimuksessa
}

\author{
Mila Oiva
}

Ian Milligan, History in the Era of Abundance? How

the Web is Transforming Historical Research. McGill-

Queen's University Press, 2019.

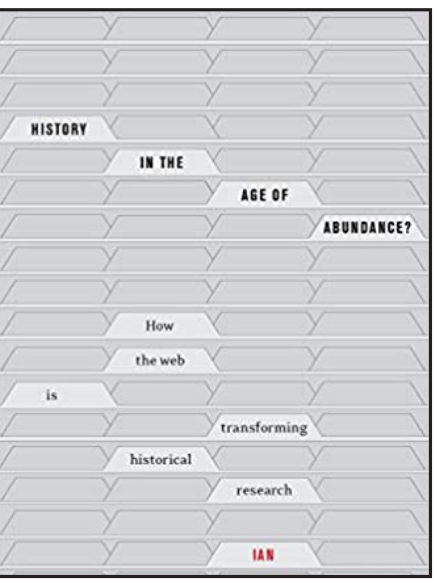

Nyt käsillä olevan ajan muuntuessa historiaksi sitä tutkitaan uudentyyppisiä aineistoja hyödyntäen. Kun lähitulevaisuuden historioitsijat alkavat yhä systemaattisemmin tutkia 1990-luvun puolivälin jälkeisen ajan poliittisia debatteja, käsitöiden tekemisen kulttuurihistoriaa tai journalismin muutosta, he tarvitsevat internetaineistoja ymmärtääkseen tutkimiaan ilmiöitä kokonaisvaltaisesti. Samanaikaisesti historiantutkimus alana on huonosti valmistautunut hyödyntämään verkkoaineistoja. Ian Milliganin teos History in the Era of Abundance? How the Web is Transforming Historical Research (McGill-Queen's University Press, 2019) pureutuu tähän haasteeseen tutustuttamalla lukijat 1990-luvun puolivälistä lähtien arkistoihin kerättyihin internetaineistoihin. Kirja tarjoaa laajan kattauksen verkon tutkimiseen historiantutkimuksen kannalta olennaisesti liittyviä teemoja edeten löyhän kronologisesti aineistojen synnyn kuvaamisesta niiden keräämiseen ja analysointiin. Milligan esittelee aineistojen luonnetta digitaalisina artefakteina, kokoelmien keräämisen ja käytön rajoitteita ja mahdollisuuksia, tarjolla olevia laajojen digitaalisten aineistokokonaisuuksien analysointiin soveltuvia menetelmiä ja ohjelmia sekä verkkoaineistojen käyttöön liittyviä vaikeita eettisiä kysymyksiä.

History in the Era of Abundance liittyy viime vuosina ilmestyneiden digitaaliseen historiantutkimukseen johdattelevien kirjojen jatkumoon. Monet julkaisut esittelevät Milliganin kirjan tavoin käytettävissä olevia tietokoneavusteisia menetelmiä ja pohtivat niiden soveltuvuutta historia-aloihin. ${ }^{1}$ Toisin kuin edeltäjänsä, Milligan keskittyy kirjassaan selkeästi yhteen aineistokokonaisuuteen ja siksi onnistuu tarkastelemaan sitä syvällisesti ja monipuolisesti. Vaikka Milligan antaa kirjassaan kiinnostavia esimerkkejä omasta tutkimuksestaan, hän ei keskity niihin. Tämän vuoksi kirjan parina kannattaakin lukea esimerkiksi Niels Brüggerin ja Ralph Schroederin toimittama Web as History: Using Web Archives to Understand the Past and the Present (UCL Press, 2017), joka antaa hyviä esimerkkejä internetaineistojen käytöstä historiantutkimuksessa.

\footnotetext{
${ }^{1}$ Elo, Kimmo, Anna Sivula, Olli Kleemola, Kimmo Elo, Lauri Viinikkala ja Jaakko Suominen. 2016. Digitaalinen humanismi ja historiatieteet. Turun historiallinen yhdistys; Graham, Shawn, lan Milligan ja Scott Weingart. 2015. Exploring Big Historical Data: The Historian's Macroscope. World Scientific Publishing Company; Parland-von Essen, Jessica. 2014. Historia i en digital värld. https://digihist.se/; Nawrotzki, Kristen ja Jack Dougherty. 2013. Writing History in the Digital Age. Ann Arbor, MI: University of Michigan Press. http:// dx.doi.org/10.3998/dh.12230987.0001.001; Kelly, T. Mills. 2013. Teaching History in the Digital Age. Digital Humanities. Ann Arbor, MI: University of Michigan Press. http://dx.doi.org/10.3998/dh.12146032.0001.001.
} 
Kirjassaan Milligan onnistuu yhtältä innostamaan tutkijaa käymään internetaineistojen pariin ja osoittamaan, millaisia uusia mahdollisuuksia internetaineistojen hyödyntäminen avaa. Samalla hän kuitenkin myös kertoo, millaisia aukkoja niissä on ja minkälaisia hankaluuksia niiden käyttämiseen liittyy. Aikaisempien sukupolvien elämästä jäi arkistoihin usein vain muutamia merkintöjä ja jokapäiväisestä arkielämästä tuskin mitään, kun taas nykyään internetin valtavirtaistumisen myötä verkkoon kasautuu valtava määrä monenlaisia lähteitä. Vaikka maailman mittakaavassa vain valikoitu joukko ihmisiä - osallisuus riippuu pitkälti asuinpaikasta, varallisuudesta, etnisyydestä ja sukupuolesta - tuottaa aineistoja internetiin, ja digitaaliset aineistot tuhoutuvat herkästi ja nopeasti, internetaineisto avaa mahdollisuuden tarkastella tavallisten ihmisten elämää ennennäkemättömässä mittakaavassa. Vaikka yksittäinen keskustelupalstakommentti ei ole välttämättä sellaisenaan historiallisesti merkittävä, sadat tuhannet kommentit yhdessä auttavat ymmärtämään niiden kirjoitusajankohtaa. Pystyäkseen kontekstualisoimaan ja tutkimaan suuria digitaalisia aineistomääriä historiantutkijoiden tulee ymmärtää internetaineistojen luonnetta ja osata käyttää tietokoneavusteisia tutkimusmenetelmiä, ja juuri näihin kysymyksiin Milligan tarjoaa vastauksia.

Teknologian historiasta kiinnostuneelle lukijalle Milligan tarjoaa kiinnostavan näkymän internetin tekniseen kehitykseen, sen standardien ja käytettävyyden kehkeytymiseen ja internetin valtavirtaistumiseen, minkä myötä internet oli kaikin puolin hyvin erilainen vuosina 1995, 2010 ja 2020. Hän myös kuvailee perinpohjaisesti, kuinka digitaalisten artefaktien kuten verkkosivujen rekonstruoiminen myöhemmin kehittyneemmillä laitteilla ja ohjelmilla on äärimmäisen vaikeaa ja kallista. Se, millaisen kokemusmaailman verkon avaaminen rätisevän modeemin kautta joskus loi, on jo ulottumattomissamme.

Internetaineistojen tutkiminen herättää vakavia eettisiä kysymyksiä. Niitä käytettäessä tulee Milliganin mukaan punnita tarkkaan, kuinka julkiseksi tekijä on sisällön tarkoittanut. Esimerkiksi poliittisen puolueen verkkosivu voidaan rinnastaa julkaisuun, mutta pienen käyttäjäryhmän keskustelupalstalla käydyt keskustelut eivät niinkään. 1990-luvulla, kun internetin käyttäjiä oli vähemmän, internet muodosti usein eräänlaisen yksityisen piirin digitaalisen ulottuvuuden, eivätkä henkilökohtaisista asioista palstoille kirjoittaneet voineet kuvitella, että tekstit olisivat myöhemmin kaikkien saatavilla. Samanaikaisesti kuitenkin internetaineistojen jättäminen tutkimuksen ulkopuolelle tarkoittaisi tavallisten ihmisten äänen vaientamista, joka Milliganin mukaan myös olisi eettisesti väärin. Tämän vuoksi historiantutkijoiden tulee käyttää vakavaa harkintaa tasapainoillessaan aineistojen eettisen käytön, tutkittavien integriteetin suojelemisen ja aineistojen tunnistettavuuden ja tutkimuksen verifioitavuuden välillä.

Kun maailman digitalisoituminen vaikuttaa historiantutkimuksen käyttämiin aineistoihin lähitulevaisuudessa entistä enemmän, Milliganin mukaan ei riitä, että historiantutkijat ainoastaan käyttävät muiden tieteenalojen kehittämiä tutkimusmenetelmiä ja ohjelmia. Kuten myös Milligan ehdottaa, meidän tulisi olla mukana monitieteisissä ryhmissä kehittämässä uusia, historiantutkimuksen periaatteet paremmin huomioon ottavia tietokoneavusteisia menetelmiä. Näin varmistamme myös jatkossa, että historiantutkimus kykenee vastaamaan olennaisiin tutkimuskysymyksiin eikä vain niihin, joihin saatavilla olevat algoritmit taipuvat. Digitalisoituvien aineistojen keskellä historiantutkijoilla ei ole varaa jättää digitaalisten tutkimusmenetelmien kehitystä muille. 